\title{
INFLUENCE OF DRIED Bacillus subtilis AND LACTOBACILLI CULTURES ON INTESTINAL MICROFLORA AND PERFORMANCE IN BROILERS
}

\author{
L. Z. Jin, Y. W. Ho', N. Abdullah ${ }^{2}$ and S. Jalaludin \\ Department of Animal Science, University Pertanian Malaysia, 43400 UPM, Serdang, Selangor, Malaysia
}

\begin{abstract}
Summary
Two hundred 10-day-old, male Arbor Acres broiler chicks divided randomly into 4 groups of 50 chicks each were used. Different feeding treatment was carried out for each group. Chicks in treatment 1 were fed a basal diet (Starter feed) (control); treatment 2 , a basal diet $+0.1 \%$ B. subtilis culture; treatment 3 , a basal diet $+0.2 \%$ lactobacilli culture in the feed; and treatment 4 , a basal diet $+5 \mathrm{~g}$ lactobacilli in the drinking water. The viable bacterial counts for each treatment were approximately $10^{9}$ cells $/ \mathrm{kg}$ feed.

The weight gain in chickens given feeds incorporated with $B$. subtilis and lactobacilli was significantly $(p<0.05)$ higher than those of the control. With regard to feed efficiency, there was a definite tendency towards a higher feed : gain ratio in the control group and those fed lactobacilli in drinking water, but those fed lactobacilli in feed had a significantly lower $(p<0.05)$ feed : gain ratio. A significantly $(p<0.05)$ larger population of Lactobacillus was found in the small intestine of chickens fed with feed incorporated with B. subtilis at 21 and 28 days and with lactobacilli at 14, 21 and 28 days. Populations of intestinal $E$. coli in broilers given feed added with $B$. subtilis were not significantly $(p<0.05)$ different from those of the control, but in chickens fed lactobacilli-added feed, their populations were significantly lower $(p<0.05)$ at 14 and 21 days. No significant differences were found among the treatments and the control in the occurrence of Salmonella and Campylobacter during the whole experimental period.
\end{abstract}

(Key Words : Broiler, Performance, Pathogenic Bacteria, Lactobacillus, B. subtilis, Probiotic)

\section{Introduction}

The concept of using microbial preparation in poultry production has become an area of great interest because continued use of sub-therapeutic levels of antibiotics in animal feeds may result in the development of drugresistant microorganisms in human. Brant et al. (1994) reported that, in America, 13,300 hospital patients had died from infections caused by bacteria which were resistant to the antibiotics prescribed by the doctors. In Malaysia, the antibiotic resistance situation is as acute as, if not worse than, that in US since antibiotics are freely available for use in animals and human. A possible

\footnotetext{
'Address reprint requests to Dr. Y. W. Ho, Department of Biology, Faculty of Science and Environmental Studies, University Pertanian Malaysia, 43400 Serdang, Selangor, Malaysia.

${ }^{2}$ Department of Biochemistry and Microbiology University Pertanian Malaysia, 43400 UPM, Serdang, Selangor, Malaysia.

Received September 28, 1995
}

Accepted February 12, 1996 alternative to antibiotics for growth promotion and improvement of feed efficiency in domestic avian species is by feeding living microbial cultures to them (Damron et al., 1981; Miles et al., 1981a,b; Goodling et al., 1987; Lyons, 1987; Fuller, 1989).

The use of microbial cultures containing lactobacilli is well documented in the temperate region, but very little information is available in the hot and humid area. Viable cells of lactobacilli fed to chickens were found to compete with undesirable microorganisms like pathogenic Escherichia coli (Mitchell and Kenworthy, 1976; Muralidhara et al., 1977; Suzuki et al., 1989) and maintain favorable microbial populations in the digestive tract of chickens. Fuller and Turvey (1971) demonstrated that lactic acid producing bacteria such as lactobacilli and streptococci were common microorganisms which were fundamental in the efficient conversion of feed for growth and production of chickens. This equilibrium of the intestinal microflora could be upset at any time when the animal is put under stress, such as excessive heat or humidity. 
There have been very few reports on the use of Bacillus subtilis culture in poultry. It has been hypothesized that $B$. subtilis will associate with the gut wall and favor the balance of beneficial intestinal microflora (Saartchit and Sullivan, 1990). There is also a lack of information on the effects of living microbial cultures on anaerobic bacteria and pathogenic Campylobacter in the intestine; the latter has been found to cause diarthea in chicken and human.

The objective of this study was to investigate the effects of dried $B$. subtilis and lactobacilli cultures on the intestinal microflora, including Campylobacter and anaerobes, and the performance of broilers in hot and humid climate.

\section{Materials and Methods}

\section{Animals}

Two hundred 10-day-old, male Arbor Acres broiler chicks were used. All the chicks were raised in wooden cages containing 10 birds each. Each cage was provided with wood shavings litter, a plastic feeder and a water fount.

\section{Cultures used}

The B. subtilis (CIP5832, Institut Pasteur) culture used was from Guyomarch Co. France, and it contained approximately $1 \times 10^{9}$ living microorganisms/g. The lactobacilli culture was from Kemin Industries, Inc., Iowa, USA, and it also contained $0.5-1 \times 10^{9}$ viable cells $/ \mathrm{g}$.

\section{Feeding treatments}

The antibiotic-free basal feed (Starter feed) was from Federal Flour Company, Malaysia. The composition and nutrient analysis of the basal feed are given in table 1 .

Four feeding treatments, with 50 chicks for each treatment, were carried out. Chicks in treatment 1 were fed a basal diet and this treatment acted as the control. Chicks in treatment 2 were given a basal diet $+0.1 \% B$. subtilis culture; in treatment 3 , a basal diet $+0.2 \%$ lactobacilli culture in the feed; and in treatment 4 , basal diet $+5 \mathrm{~g}$ lactobacilli in the drinking water per cage per day. The experimental period for all the treatments was 28 days. The feed and water were provided ad libitum throughout the experimental period. The basal feed and drinking water given to the chicks in all the treatments were checked for bacterial ( $E$. coli, Lactobacillus, Salmonella and Campylobacter) contamination.

The chickens in each treatment were weighed in groups of ten at the beginning and end of the experiment. Feed consumed by the ten chickens in each cage was
TABLE 1. COMPOSITION AND NUTRITION ANALYSIS OF BASAL DIET

\begin{tabular}{lc}
\hline Composition & $\begin{array}{c}\text { Starter }(0-3 \mathrm{wk}) \\
(\%)\end{array}$ \\
\hline Corn & 59.00 \\
Fishmeal & 2.50 \\
Soybean meal & 28.00 \\
Corn gluten meal & 3.00 \\
Palm oil & 2.20 \\
Dicalcium phosphate & 1.30 \\
Vitamin premix & 0.50 \\
Mineral premix & 0.50 \\
Limestone powder & 1.00 \\
DL-methionine & 0.60 \\
Choline chloride & 1.40 \\
Total & 100.00 \\
\hline Nutrient analysis & $(\%)$ \\
\hline Crude protein & 22.00 \\
Crude fiber & 4.42 \\
ME (MJ/kg) & 12.51 \\
Ash & 5.48 \\
Ca & 1.03 \\
Available phosphorus & 0.54 \\
Lysine & 1.23 \\
Methionine \& cysteine & 0.93 \\
\hline (Source: Fedel Fur Cong
\end{tabular}

(Source : Federal Flour Company, Selangor, Malaysia)

recorded, and feed efficiencies were calculated. Mortality of the chickens in each treatment was also recorded. Temperature and humidity of the surrounding environment were measured daily using a thermohydrometer.

\section{Isolation and enumeration of intestinal microflora}

Intestinal microflora of chickens fed with the four different feeding treatments was examined at $0,7,14,21$ and 28 days of the experiment. Three birds from each treatment were randomly selected and sacrificed by severing the jugular vein. Samples from the small intestine were used for isolation of Lactobacillus and Enterobacter, and samples from the cecum were used for Campylobacter and Salmonella isolation.

Approximately $1 \mathrm{~g}$ of intestinal content was mixed with $9 \mathrm{ml}$ of sterile blank dilution solution (Bryant and Burkey, 1953), and homogenized (3 min) using a homogenizer. The mixture was diluted in a 10 -fold dilution series to $10^{-7}$ for intestinal samples and $10^{-9}$ for cecal samples. For each dilution, $0.1 \mathrm{ml}$ was overlaid with agar medium Four media were used. They were, BCP Plate Counting Agar (Eiken Chemical Co., Ltd., Tokyo, 
Japan) for Lactobacillus, MacConkey agar (Oxoid, England) for Enterobacter, XLD Medium agar (Oxoid, England) for Salmonella, and Campylobacter Blood-free Selective Agar Base (Oxoid, England) for Campylobacter. All the plates were then incubated at $37^{\circ} \mathrm{C}$. For isolation of Enterobacter, the plates were incubated for $24 \mathrm{~h}$, for Campylobacter and Salmonella, $48 \mathrm{~h}$, and for Lactobacillus, 72 h. Petri dishes which had 30 to 300 colonies were counted using a colony counter (Funke Gerber, Germany). Duplicates were made for each dilution and each medium used.

For isolation and estimation of facultative anaerobic bacteria, a total of 12 chickens were selected at the end of the experimental period and anesthetized completely with chloroform. Methods for the isolation and estimation of the facultative anaerobes from the contents of the duodenum, ileum and cecum were the same as those described above, except the isolation was carried out under anaerobic conditions. FM98-5 medium (Jin et al., 1994) and roll tubes instead of petri dishes were used for isolating and counting of the facultative anaerobes (Hungate, 1969).

\section{Statistics}

Mean values between treatments were compared by Least Significance Difference (LSD) using Statistical Graphic System (STATIGRAPHIC, USA).

\section{Results}

The average maximum and minimum temperatures during the experimental period were $34.8^{\circ} \mathrm{C}$ and $24.8^{\circ} \mathrm{C}$ respectively, and the average relative humidity was $97 \%$.

Bacterial populations present in the basal feed and drinking water are shown in table 2 . The numbers of $E$.

TABLE 2. BACTERIAL POPULATION IN BASAL FEED AND DRINKING WATER USED IN THE EXPERIMENT

\begin{tabular}{llcc}
\hline & \multicolumn{3}{c}{$\begin{array}{c}\text { Bacterial population } \\
\text { (Log CFU/g or } \mathrm{ml})\end{array}$} \\
\cline { 2 - 4 } Bacteria & Feed & $\begin{array}{c}\text { Drinking } \\
\text { water }\end{array}$ & Cultures \\
\hline E. coli & 2.98 & 2.08 & NT \\
Lactobacillus & 2.70 & 0 & 8.95 \\
Salmonella & 0 & 0 & NT \\
Campylobacter & 0 & 0 & NT \\
B. subtilis & NT & NT & 9.00 \\
\hline
\end{tabular}

NT $=$ Not tested.

$\mathrm{CFU}$, colony-forming unit. coli and Lactobacillus were too low to cause any effects on the animal performances. Salmonella and Campylobacter were not found in both the basal feed and drinking water.

The average weight gain, feed efficiency and percentage of mortality of the chickens in the four feeding treatments are shown in table 3. It can be seen that the average weight gain was significantly more $(p<0.05)$ in chicken given feeds incorporated with $B$. subtilis and lactobacilli. When lactobacilli were added to the drinking water, the weight gain was not significantly different $(p>$ 0.05) from that of the control. With regard to feed efficiency, there was a definite tendency towards a higher feed:gain ratio in the control group and those fed lactobacilli in drinking water, but those fed lactobacilli in feed had significantly lower $(p<0.05)$ feed : gain ratio than the control There were no significant differences in the percentage of mortality of chickens in all the four feed treatments.

TABLE 3. INFLUENCE OF FEEDS INCORPORATED WITH B. SUBTILIS AND LACTOBACILLI CULTURES ON BODY WEIGHT GAIN, FEED EFFICIENCY AND MORTALITY OF BROILERS

\begin{tabular}{|c|c|c|c|c|c|}
\hline \multirow[b]{2}{*}{ Treatment } & \multicolumn{3}{|c|}{ Body weight (g) } & \multirow[b]{2}{*}{$\begin{array}{l}\text { Feed/ } \\
\text { Gain }\end{array}$} & \multirow{2}{*}{$\begin{array}{c}\text { Morta- } \\
\text { lity } \\
(\%)\end{array}$} \\
\hline & $\begin{array}{l}\text { Initial } \\
\text { wt. }\end{array}$ & $\begin{array}{c}\text { Final } \\
\text { wt. }\end{array}$ & Gain & & \\
\hline Control & 283.04 & $1,643.33$ & $1,360.29^{b}$ & $1.88^{\mathrm{a}}$ & $6.0^{\mathrm{a}}$ \\
\hline $\begin{array}{l}\text { B. subtilis } \\
\text { (feeding) }\end{array}$ & 277.61 & $1,714.33$ & $1,436.72^{\mathrm{a}}$ & $1.80^{\mathrm{ab}}$ & $4.0^{\mathrm{a}}$ \\
\hline $\begin{array}{l}\text { Lactobacilli } \\
\text { (feeding) }\end{array}$ & 276.09 & $1,734.00$ & $1,457.91^{\mathrm{a}}$ & $1.72^{\mathrm{b}}$ & $2.0^{\mathrm{a}}$ \\
\hline $\begin{array}{l}\text { Lactobacilli } \\
\text { (drinking) }\end{array}$ & 276.96 & $1,689.00$ & $1,412.04^{\mathrm{ab}}$ & $1.85^{\mathrm{a}}$ & $4.0^{\mathrm{a}}$ \\
\hline
\end{tabular}

${ }^{a, b}$ Means with different superscripts in the same column are significantly different at $\mathrm{p}<0.05$.

A significantly $(\mathrm{p}<0.05)$ larger population of intestinal Lactobacillus was found in chickens fed with feed incorporated with $B$. subtilis after 21 and 28 days and with lactobacilli, after 14,21 and 28 days (table 4). However, there were no significant differences between the populations of intestinal Lactobacillus of the control chickens and those which had lactobacilli added in their drinking water throughout the experimental period.

Populations of intestinal $E$. coli in broilers fed feed incorporated with $B$. subtilis were not significantly $(\mathrm{p}>$ 0.05 ) different from that of the control, but populations of intestinal $E$. coli in chickens fed lactobacilli added in feed were significantly lower $(p<0.05)$ at 14 and 21 
TABLE 4. POPULATIONS OF INTESTINAL LACTOBACILLUS FROM BROILERS FED FEEDS INCORPORATED WITH $B$. SUBTILIS AND LACTOBACILLI CULTURES AT 0 TO 28 DAYS POST FEEDING

\begin{tabular}{lccccc}
\hline \multirow{2}{*}{ Treatment } & \multicolumn{5}{c}{ Population of intestinal Lactobacillus (Log CFU/g) } \\
\cline { 2 - 6 } & $0 \mathrm{~d}$ & $7 \mathrm{~d}$ & $14 \mathrm{~d}$ & $21 \mathrm{~d}$ & $28 \mathrm{~d}$ \\
\hline Control & $7.25 \pm 0.30^{\mathrm{a}}$ & $7.14 \pm 0.22^{\mathrm{a}}$ & $7.61 \pm 0.05^{\mathrm{b}}$ & $7.50 \pm 0.58^{\mathrm{b}}$ & $7.64 \pm 0.13^{\mathrm{b}}$ \\
B. subtilis (feeding) & $7.44 \pm 0.45^{\mathrm{a}}$ & $7.96 \pm 0.42^{\mathrm{a}}$ & $8.20 \pm 0.50^{\mathrm{b}}$ & $9.07 \pm 0.07^{\mathrm{a}}$ & $8.91 \pm 0.51^{\mathrm{a}}$ \\
Lactobacilli (feeding) & $7.29 \pm 0.33^{\mathrm{a}}$ & $7.64 \pm 0.40^{\mathrm{a}}$ & $9.22 \pm 0.25^{\mathrm{a}}$ & $8.87 \pm 0.46^{\mathrm{a}}$ & $9.27 \pm 0.12^{\mathrm{a}}$ \\
Lactobacilli (drinking) & $7.14 \pm 0.21^{\mathrm{a}}$ & $7.04 \pm 0.45^{\mathrm{a}}$ & $7.98 \pm 0.09^{\mathrm{b}}$ & $8.02 \pm 0.16^{\mathrm{ab}}$ & $7.61 \pm 0.24^{\mathrm{b}}$ \\
\hline
\end{tabular}

Values represent Mean $\pm \mathrm{SE}$.

${ }^{a, b}$ Means with different superscripts in the same column are significantly different at $p<0.05$.

CFU, colony-forming unit per gram intestinal content.

d, days postfeeding.

TABLE 5. POPULATIONS OF INTESTINAL E. COLI FROM BROILERS FED WITH OR WITHOUT B. SUBTILIS AND LACTOBACILIII CULTURES

\begin{tabular}{lccccc}
\hline \multirow{2}{*}{ Treatment } & \multicolumn{5}{c}{ Population of intestinal E. coli (Log CFU/g) } \\
\cline { 2 - 6 } & $0 \mathrm{~d}$ & $7 \mathrm{~d}$ & $14 \mathrm{~d}$ & $21 \mathrm{~d}$ & $28 \mathrm{~d}$ \\
\hline Control & $6.30 \pm 0.21^{\mathrm{a}}$ & $6.67 \pm 0.47^{\mathrm{a}}$ & $7.28 \pm 0.15^{\mathrm{a}}$ & $7.45 \pm 0.36^{\mathrm{a}}$ & $7.58 \pm 0.09^{\mathrm{a}}$ \\
B. subtilis (feeding) & $6.48 \pm 0.30^{\mathrm{a}}$ & $6.56 \pm 0.17^{\mathrm{a}}$ & $6.96 \pm 0.09^{\mathrm{ab}}$ & $6.91 \pm 0.76^{\mathrm{ab}}$ & $6.99 \pm 0.50^{\mathrm{a}}$ \\
Lactobacilli (feeding) & $6.18 \pm 0.19^{\mathrm{a}}$ & $6.19 \pm 0.59^{\mathrm{a}}$ & $6.47 \pm 0.35^{\mathrm{b}}$ & $6.48 \pm 0.18^{\mathrm{b}}$ & $7.00 \pm 0.50^{\mathrm{a}}$ \\
Lactobacilli (drinking) & $6.43 \pm 0.34^{\mathrm{a}}$ & $6.23 \pm 0.44^{\mathrm{a}}$ & $6.61 \pm 0.17^{\mathrm{ab}}$ & $6.69 \pm 0.49^{\mathrm{ab}}$ & $7.07 \pm 0.16^{\mathrm{a}}$ \\
\hline
\end{tabular}

Values represent Mean $\pm \mathrm{SE}$.

${ }^{a, b}$ Means with different superscripts in the same column are significantly different at $p<0.05$.

$\mathrm{CFU}$, colony-forming unit per gram intestinal content.

d, days postfeeding.

days (though not significant at 28 days) (table 5). When lactobacilli were given to the chickens in drinking water, the population of intestinal $E$. coli was not significantly different $(\mathrm{p}>0.05)$ from that of the control.

Table 6 shows the occurrence of cecal Salmonella and Campylobacter of chickens fed the four different dietary treatments. No significant differences were found among the treatments and the control in the occurrence of cecal
Salmonella and Campylobacter in chickens during the whole experimental period.

There were no significant differences in the populations of facultative anaerobic bacteria among the control and treatment groups of chicken (table 7). It can be seen that the addition of $B$. subtilis and lactobacilli to the feed did not affect significantly the populations of facultative anaerobic bacteria in the duodenum, ileum and

TABLE 6. INFLUENCE OF B. SUBTILIS AND LACTOBACILLI CULTURES ON THE OCCURRENCE OF CECAL SALMONELA AND CAMPYLOBACTER AT 14 TO 28 DAYS POST FEEDING

\begin{tabular}{|c|c|c|c|c|c|c|}
\hline \multirow[b]{2}{*}{ Treatment } & \multicolumn{3}{|c|}{ Occurrence of cecal Salmonella } & \multicolumn{3}{|c|}{ Occurrence of cecal Campylobacter } \\
\hline & $\begin{array}{l}\text { No. of } \\
\text { chickens } \\
\text { examined }\end{array}$ & $\begin{array}{c}\text { No. of } \\
\text { positive } \\
\text { birds }\end{array}$ & $\begin{array}{l}\text { Log } \\
\text { CFU }\end{array}$ & $\begin{array}{l}\text { No. of } \\
\text { chickens } \\
\text { examined }\end{array}$ & $\begin{array}{c}\text { No. of } \\
\text { positive } \\
\text { birds }\end{array}$ & $\begin{array}{l}\text { Log } \\
\text { CFU }\end{array}$ \\
\hline Control & 9 & 1 & 4.27 & 9 & 5 & $6.62-8.22$ \\
\hline B. subtilis (feeding) & 9 & 0 & - & 9 & 4 & $5.40-7.81$ \\
\hline Lactobacilli (feeding) & 9 & 1 & 4.06 & 9 & 4 & $5.93-8.36$ \\
\hline Lactobacilli (drinking) & 9 & 1 & 4.41 & 9 & 5 & $7.06-8.24$ \\
\hline
\end{tabular}

$\mathrm{CFU}$, colony-forming unit per gram intestinal content. 
TABLE 7. POPULATIONS OF FACULTATIVE ANAEROBIC BACTERIA IN THE DUODENUM, ILEUM AND CECUM OF BROILERS FED DIETS ADDED WITH OR WITHOUT B. SUBTILIS AND LACTOBACILLI CULTURES

\begin{tabular}{llcc}
\hline \multirow{2}{*}{ Treatment } & \multicolumn{3}{c}{$\begin{array}{c}\text { Population of facultative an aerobe } \\
\text { (Log CFU/g) }\end{array}$} \\
\cline { 2 - 4 } & Duodenum & lleum & Cecum \\
\hline $\begin{array}{c}\text { Control } \\
\text { B. subtilis } \\
\text { (feeding) }\end{array}$ & $6.13 \pm 0.36^{\mathrm{a}}$ & $7.75 \pm 0.05^{\mathrm{b}}$ & $11.01 \pm 0.07^{\mathrm{a}}$ \\
$\begin{array}{c}\text { Lactobacilli } \\
\text { (feeding) }\end{array}$ & $5.93 \pm 0.47^{\mathrm{a}}$ & $7.20 \pm 0.36^{\mathrm{b}}$ & $10.95 \pm 0.09^{\mathrm{a}}$ \\
$\begin{array}{c}\text { Lactobacilli } \\
\text { (drinking) }\end{array}$ & $6.53 \pm 0.08^{\mathrm{a}}$ & $7.87 \pm 0.14^{\mathrm{ab}}$ & $10.82 \pm 0.35^{\mathrm{a}}$ \\
\hline
\end{tabular}

Values represent Mean $\pm \mathrm{SE}$.

${ }^{2 b}$ Means with different superscripts in the same column are significantly different at $\mathrm{p}<0.05$.

$\mathrm{CFU}$, colony forming unit per gram intestinal content.

cecum of broilers throughout the experimental period.

\section{Discussion}

The results of this study showed that there was an increase $(p<0.05)$ in body weight gain of broilers and an improvement $(\mathrm{p}<0.05)$ in feed efficiency when $B$. subtilis and lactobacilli cultures were added to their diets. Although there is a lack of available information on the use of $B$. subtilis culture as a growth promotant in chickens, it has been suggested that $B$. subtilis culture, when fed to poultry, would associate with the gut wall and favor an increase in the numbers of natural Lactobacillus, which, in turn, may suppress undesirable enteric microorganisms such as $E$. coli. The present results showed that an addition of $0.1 \%$ B. subtilis culture in the diet of chickens could increase their intestinal Lactobacillus population after 21 and 28 days of feeding; however, there was no decrease in the intestinal $E$. coli populations. These results support, in part, the above hypothesis. In contrast, Saartchit and Sullivan (1990) found that ingestion of $B$. subtilis culture had no significant effect on the populations of intestinal Lactobacillus and $E$. coli in turkeys.

The effects of lactobacilli cultures on the growth of domestic avian species have been studied extensively. Tortuiero (1973) and Alder and DaMassa (1980) reported that feeding a Lactobacillus culture to chicks improved their body weight gain. Couch (1978) fed a probiotic to commercial broilers at a rate of $454 \mathrm{~g} / \mathrm{ton}$ and found that
Lactobacillus-supplemented birds had an increase in average weight gain and feed conversion. Kalbande et al. (1992) also found that growing pullets fed with a diet added with $0.02 \%$ probiotic (Lactobacillus sporogenes spores) significantly increased body weight gain and feed efficiency. However, Watkins and Kratzer (1983a,b) observed that broilers raised in battery brooders and fed a diet or drinking water containing Lactobacillus culture did not perform as well as the control birds or those fed antibiotics. Lyons (1987) suggested that the effectiveness of probiotic addition was related to two factors, namely, correct numbers of living bacteria used and the presence of stress on the chicken. The results of the present experiment where there was an increase in body weight gain and feed efficiency when Lactobacillus cultures were added to the diets of broilers support this theory as the experimental broilers were reared in hot (average temp. $29.3^{\circ} \mathrm{C}$ ) and humid $(97 \%)$ climate which has been found to be stressful to the chickens (Andersson, 1977). It is not known, from the results of this study, why the addition of lactobacilli in the drinking water failed to increase significantly the performance of the broilers.

The present result which showed a decrease in the populations of the intestinal $E$. coli in broilers fed a diet added with lactobacilli agrees with the findings of Mitchell and Kenworthy (1976) and Suzuki et al. (1989) and supports the hypothesis that lactobacilli compete with coliform for sites of adherence on the intestinal surface. Muralidhara et al. (1977) also found that homogenates of washed intestinal tissues collected from piglets dosed with L. lactis had markedly higher numbers of attached Lactobacillus and lower numbers of $E$. coli than scouring or normal control pigs.

There has been a great deal of interest to prevent Salmonella infection in chickens because infected birds can serve as a source of infection for human, and human infection can result in serious illness or even death (Ziprin and Deloach, 1993). Rantala and Nurmi (1973) and Snoeyenbos et al. (1978) pioneered the use of a probiotic culture, and showed that the probiotic had the ability to prevent the establishment of Salmonella infantis in the ceca of chicks although, in this case, lactobacilli were not the only organism present. Shanhani et al. $(1976,1977)$ reported that lactobacilli could inhibit the growth of Salmonella in vitro. Goren et al. (1984) and Impey and Mead (1989) pointed out that microbial cultures should be given to chicks very early in life, preferably before the chicks were exposed to Salmonella. In the present study, the results indicates that both Lactobacillus and $B$. subtilis cultures fed to broilers do not have an effect on the occurrence of Salmonella in the ceca of the broilers 
throughout the experimental period. Further study is needed to confirm this point.

Supplementation of lactobacilli in feed and drinking water or B. subtilis in feed did not seem to suppress infection by Campylobacter in the present experiment. Throughout the 28-day experimental period, the occurrence of Campylobacter among the broilers in the treatment groups and the control were not significantly different. Apart from Soerjadi et al. $(1982,1984)$ who reported that chicks colonized by native gut microflora were relatively resistant to subsequent colonization by some strains of Campylobacter, there is no other information on the effect of gut microflora on Campylobacter.

In conclusion, the present study demonstrates that the additions of $B$. subtilis and lactobacilli in the feeds of broilers improve the performance of the broilers, enhance their intestinal Lactobacillus population and suppress intestinal $E$. coli numbers, but they have no effect on the colonization of pathogenic cecal Salmonella and Campylobacter of broilers.

\section{Acknowledgements}

The funds provided by the Ministry of Science and the Environment of Malaysia under the Intensification of Research Priority Areas (IRPA) Program (Project Code 107-05-038) are acknowledged.

\section{Literature Cited}

Adler, H. E. and A. J. DaMassa. 1980. Effect of ingested lactobacilli on Salmonella infantis and $E$. coli and intestinal flora, pasted vents and chick growth. Avian Diseases. 24:868-878.

Andersson, B. E. 1977. Temperature Regulation and Environmental Physiology. In “Dukes' Physiology of Domestic Animals". (M. J. Swenson ed.) pp. 686-695. Ithaca and London.

Brant, M., P. Wingert and M. Hager. 1994. The end of antibiotics. Newsweek. March, 28:35-39.

Brant, M. P. and L. A. Burkey. 1953. Cultural methods and some characteristics of some of the more numerous groups of bacteria in the bovine rumen. Journal of Dairy Science. 36:205-217.

Couch, J. R. 1978. Poultry researchers outline benefits of bacteria, fungistatic compounds, other feed additives. Feedstuffs. 50(14):6.

Damron, B. L., H. R. Wilson, R. A. Vottle and R. H. Harms. 1981. A mixed Lactobacillus culture in the diet of broad breasted large white turkey hens. Poultry
Science. 60:1350-1351.

Fuller, R. and A. Turvey. 1971. Bacteria associated with the intestinal wall of the fowl (Gallus domesticus). Journal of Applied Bacteriology. 34:617-622.

Fuller, R. 1989. Probiotics in man and animals. Journal of Applied Bacteriology. 66:365-378.

Goodling, A. C., G. J. Cerniglia and J. A. Hebert. 1987. Production performance of White Leghorn layers fed Lactobacillus fermentation products. Poultry Science. 66:480-486.

Goren, E., W. A. deJong, P. Doornebal, J. P. Koopman and H. M. Kennis. 1984. Protection of chicks against Salmonella infection induced by spray application of intestinal microflora in the hatchery. Veterinary Quarterly. 6:73-79.

Hungate, R. E. 1969. A Roll Tube Method for Cultivation of Strict Anaerobes. In "Methods in Microbiology" Vol. 3B. (J. R. Norris and D. W. Ribbons eds.). pp. 117-132. Academic Press Inc., New York.

Impey, C. S. and G. C. Mead. 1989. Fate of Salmonella in the alimentary tract of chicks pretreated with a mature cecal microflora to increase colonization resistance. Journal of Applied Bacteriology. 66:469475.

Jin, L. Z., N. Abdullah, Y. W. Ho and S. Jalaludin. 1994. Comparison of different media for isolation of anaerobic bacteria from the duodenum, jejunum and cecum of chicken. In "Challenges in Microbiology for the 21st Century-- Proceeding of 17th Malaysian Microbiology Symposium." pp. 87-90. Penang, Malaysia.

Kalbande, V. H., M. A. Gaffar, S. V. Deshmukh. 1992. Effect of probiotic and nitrofurin on performance of growing commercial pullets. Indian Journal of Poultry Science. 27:116-117.

Lyons, T. P. 1987. Probiotics: an altemative to antibiotics. Pig News and Information. 8:157-164.

Miles, R. D., H. R. Wilson, A. S. Arafa, E. C. Coligado and D. R. Ingram. 1981 a. The performance of Bobwhite quail fed diets containing Lactobacillus. Poultry Science. 60:891-896.

Miles, R. D., A. S. Arafa, R. H. Harms, C. W. Carlson, B. L. Reid and J. S. Crawford. 1981b. Effects of living non-freeze dried Lactobacillus acidophilus culture on performance, egg quality and gut microflora in commercial layers. Poultry Science. 60:993-1004.

Mitchell, I. and R. Kenworthy. 1976. Investigations on a metabolite of Lactobacillus bulgaricus which neutralizes the effect of enterotoxin from pathogenic E. coli for pigs. Journal of Applied Bacteriology. 31:163-174. 
Muralidhara, K. S., G. G. Sheheby, P. R. Elliker, D. C. England and W. E. Sandine. 1977. Effect of feeding lactobacilli on the coliform and Lactobacillus flora of intestinal tissue and feces from piglets. Journal of Food Protection. 40:288.

Rantala, M. and E. Nurmi. 1973. Prevention of the growth of Salmonella infantis in chicks by the flora of the alimentary tract of chickens. British Poultry Science. 14:627-630. .

Saartchit, T. and T. W. Sullivan. 1990. Influence of a dried Bacillus subtilis culture and antibiotics on performance and intestinal microflora in turkeys. Poultry Science. 69:1966-1973.

Shanhani, K. M., J. R. Vakil and A. Kilara. 1976. Natural antibiotic activity of Lactobacillus acidophilus and $L$. bulgaricus. 1. Cultural conditions for the production of antibiosis. Cultured Dairy Products Journal. 11:1417.

Shanhani, K. M., J. R. Vakil and A. Kilara. 1977. Natural antibiotic activity of Lactobacillus acidophilus and $L$ bulgaricus. 2. Isolation of acidophilin from $L$. acidophilus. Cultured Dairy Products Journal. 12:8-11.

Snoeyenbos, G. H., O. M. Weinack and C. F. Smyser. 1978. Protecting chicks and poults from Salmonellae by oral administration of "normal" gut microflora. Avian Disease. 22:273-287.
Soerjadi, A. S., G. H. Snoeyenbos and O. M. Weinack. 1982. Intestinal colonization and competitive exclusion of Campylobacter fetus subsp. jejuni in young chicks. Avian Disease. 26:520-524.

Soerjadi, A. S., G. H. Snoeyenbos and O. M. Weinack. 1984. Comparative studies on competitive exclusion of three isolates of Campylobacter fetus sub. sp. jejuni in chickens by native gut microflora. Avian Disease. 28:139-146.

Suzuki, K., Y. Kodama and T. Mitsuoka. 1989. Stress and intestinal flora. Bifidobacteria and Microflora. 8:23-38.

Tortuero, F. 1973. Influence of implantation of Lactobacillus acidophilus in chicks on the growth, feed conversion, malabsorption of fats syndrome and intestinal flora. Poultry Sciece. 52:197-203.

Watkins, B. A. and F. H. Kratzer. 1983a. Effect of oral dosing of Lactobacillus strains on gut colonization and liver biotin in broiler chicks. Poultry Science. 62:2088-2094.

Watkins, B. A. and F. H. Kratzer. 1983b. Drinking water treatment with commercial preparation of a concentrated Lactobacillus culture for broiler chickens. Poultry Science. 63:1671-1673.

Ziprin, R. L. and J. R. Deloach. 1993. Comparsion of probiotics maintained by in vivo passage through laying hens and broilers. Poultry Science. 77:628-635. 
$\ldots \ldots \ldots$ 